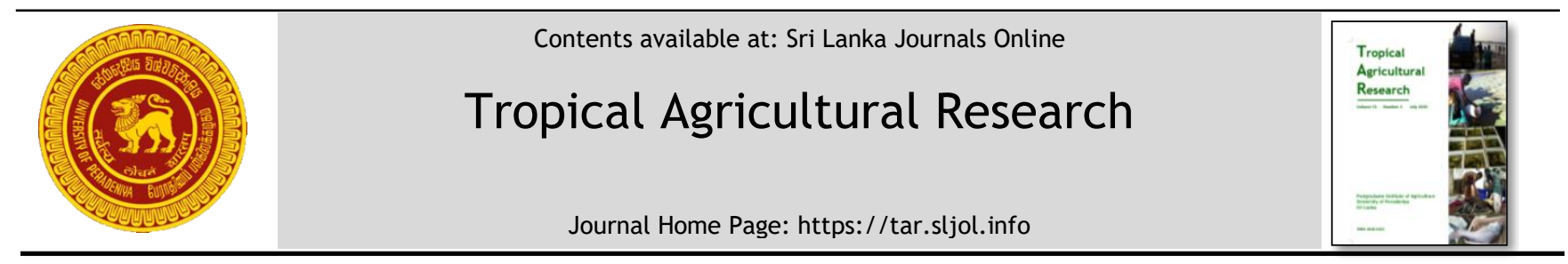

\title{
Effect of 1- MCP on Physico-Biochemical Properties and Delayed Ripening of 'Ambul' Banana at Ambient Conditions
}

\author{
W.M.C.B. Wasala ${ }^{1 *}$, C.K. Beneragama 2 , K.H. Sarananda ${ }^{3}$ and G.D.K. Kumara ${ }^{4}$ \\ ${ }_{1}^{1}$ Postgraduate Institute of Agriculture, University of Peradeniya, Peradeniya, Sri Lanka. \\ ${ }^{2}$ Department of Crop Science, Faculty of Agriculture, University of Peradeniya, Peradeniya, Sri Lanka. \\ ${ }^{3}$ Department of Biosystems Engineering, Faculty of Agriculture and Plantation Management, Wayamba University of Sri \\ Lanka, Kuliyapitiya, Sri Lanka. \\ ${ }^{4}$ Department of Export Agriculture, Faculty of Agricultural Sciences, Sabaragamuwa University of Sri Lanka, Belihuloya, \\ Sri Lanka.
}

\section{ARTICLE INFO}

\section{Article history:}

Received: 19 September 2019

Accepted: 10 November 2019

Revised version received: 15 June 2020

Available online: 01 July 2020

\section{Keywords:}

'Ambul' banana

Ethylene

1-MCP

Ripening

\section{Citation:}

Wasala, W.M.C.B., Beneragama, C.K., Sarananda K.H. and Kumara G.D.K. (2020). Effect of 1- MCP on Physico Biochemical Properties and Delayed Ripening of 'Ambul' Banana at Ambient Conditions. Tropical Agricultural Research, 31(3): 37-47.

DOI: http://doi.org/10.4038/tar.v31i3.8395

Wasala, W.M.C.B.

https://orcid.org/0000-0002-0016-9987

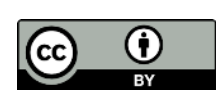

\section{ABSTRACT}

The present study was conducted to determine the effect of different concentrations and exposure periods of 1-MCP on physiological and biochemical qualities of 'Ambul' banana at ambient conditions. Combinations of 0.5 and 1 ppm concentrations of 1-MCP and 12 and $18 \mathrm{~h}$ of exposure periods were used. Ethylene production, respiration rate, ascorbic acid content, $\mathrm{pH}$, titratable acidity (TA), sugar content and pulp-to-peel ratio were measured at initial stage and during the storage period. 1-MCP treated 'Ambul' banana fruit significantly $(\mathrm{p} \leq 0.05)$ delayed the peak of ethylene production. Fruits treated with $0.5 \mathrm{ppm}$ of $1 \mathrm{MCP}$ for 12 and $18 \mathrm{~h}$ delayed the peak of ethylene emission by 13 days, while the fruit exposed to the higher dose (1 ppm) for 12 and $18 \mathrm{~h}$ delayed the same by 17 and 19 days respectively. Non-treated control fruits exhibited peak ethylene emission on day 5. Pulp-to-peel ratio of banana increased from 2.42 to 7.58 with ripening. Fruits treated with the higher dose of $1 \mathrm{MCP}$ for $18 \mathrm{~h}$ showed the least rate of increase in pulp-to-peel ratio indicating the delayed ripening. Pulp $\mathrm{pH}$ significantly $(\mathrm{p} \leq 0.05)$ decreased within first five days in the control compared to treatments. All the treatments and control exhibited increase in sucrose, fructose and glucose contents during storage period while the lowest change in sugar content during storage period was shown by fruits treated with the higher dose of $1 \mathrm{MCP}$ for $18 \mathrm{~h}$. In conclusion, exposing banana fruits to 1-MCP at the dose of $1 \mathrm{ppm}$ for $18 \mathrm{~h}$ extended the shelf life of 'Ambul' banana for 19 days under ambient conditions with a desirable marketable quality.

\footnotetext{
*Corresponding author : wasala73@yahoo.com
} 


\section{INTRODUCTION}

Banana (Musa spp.) is the most widely cultivated and consumed fruit in Sri Lanka (Hirimburegama et al., 2004). There are about 47,096 ha of land area under banana cultivation in Sri Lanka and the annual production is about 62,549 tons in 2017 (www.knoema.com). High postharvest losses, estimated to be 20 - $30 \%$ of total production, is considered as one of the major problems in banana industry due to improper handling practices and short postharvest life (Wasala et al., 2014). Although a number of banana cultivars are grown in Sri Lanka, cultivar 'Ambul' is the most widely cultivated and consumed banana type. Moreover, there is a high export demand for this cultivar due to its unique taste and small finger size (Jinasena et al., 2011).

Banana is a typical climacteric fruit. When ripening process is initiated with ethylene, the shelf-life is shortened because of rapid deterioration of peel colour and pulp firmness (Seymour et al., 1993). Thus, prevention of or delaying the effect of ethylene on ripening of banana is of great importance in increasing shelf life. One such method is, making transgenic plants with altered ethylene production levels and with chemical inhibitors of ethylene reception (Zhang et al., 2006), which is not a feasible solution for a developing country like Sri Lanka. Prolonging the postharvest life of 'Ambul' banana is one of the major solutions to develop the banana industry in Sri Lanka, which will contribute to increased export volume, and thereby more foreign exchange earnings. One method to prolong the shelf-life of banana is the use of Controlled Atmosphere (CA), which involves high capital. Another method is Modified Atmosphere (MA). However, the general benefits of MA with ethylene scrubbers are limited since temperature increase can adversely effect on fruit quality and shelf life (Silva et al., 2010).

1-methylcyclopropene (1-MCP) is relatively a new chemical which has successfully been identified for extending the shelf-life and maintaining the quality of plant-products. It is stable at room temperature, active at very low concentrations $(2.5 \mathrm{~nL} / \mathrm{L}-1 \mu \mathrm{L} / \mathrm{L})$ and importantly, it is a non-toxic GRAS (Generally Recognized As Safe) compound recommended by United States Department of Agriculture (Blankenship and Dole, 2003). Silva et al. (2010) confirmed that 1-MCP delayed ripening process banana. Further, Jiang et al. (1999) reported that 1-MCP treatment has extended the green life of Cavendish bananas. Therefore, application of 1-MCP to delay the ripening and to preserve the quality of banana will be a potential method to be used in Sri Lanka. The present study was conducted to investigate the effect of 1-MCP on 'Ambul' banana and to examine the physiological and biochemical changes related to banana ripening when fruits are stored at ambient conditions after treating with 1-MCP.

\section{MATERIALS AND METHODS}

\section{Plant material}

The local banana cultivar, 'Ambul' (AAB), was used in this study. Fully mature (3/4 quarters full) green banana bunches were obtained from a well-maintained commercial cultivation. Banana hands were separated and sorted to eliminate damaged fruits and to obtain the samples of uniform maturity.

\section{Treatment with 1-methylcyclopropene (1-MCP)}

Glass chambers (95 L capacity), which can be sealed to make air-tight during the treatment period were used to place banana fruits for 1MCP treatments. Thermocouples were fixed to glass chambers to measure the inside temperature during the treatment period (Figure 1).

\section{Determination of the best dosage of 1- MCP:}

The optimum dosage of 1-MCP was determined using two different concentrations ( 0.5 and $1 \mathrm{ppm}$ ) which were decided based on our preliminary studies and, exposing either for 12 or 18 hours. All the experiments were conducted at room temperature. The control was maintained without any 1-MCP treatments. Each treatment was replicated three times. Altogether, four treatments and control; $\mathrm{T} 1=0.5 \times 12$ (Concentration; ppm $\mathrm{x}$ Exposure 
time; hours), T2 $=0.5 \times 18, \mathrm{~T} 3=1 \times 12, \mathrm{~T} 4=1 \times 18$, and $\mathrm{C}=$ Control.

\section{Effect of 1-MCP on shelf life of banana fruits}

After treating with 1-MCP, banana hands were removed from the glass chambers and placed in plastic containers with sufficient ventilation. Physico-chemical quality parameters such as ethylene production, $\mathrm{CO}_{2}$ production, pulp-to-peel ratio, ascorbic acid, sugars and titratable acidity of banana fruit were measured at initial stage (before treatments) and after the treatments. During the storage period physico-chemical parameters were measured at every two-day interval until banana samples were fully ripen. All the experiments were conducted at ambient temperature of $29 \pm 5^{\circ} \mathrm{C}$ and relative humidity $69 \pm 7 \%$.

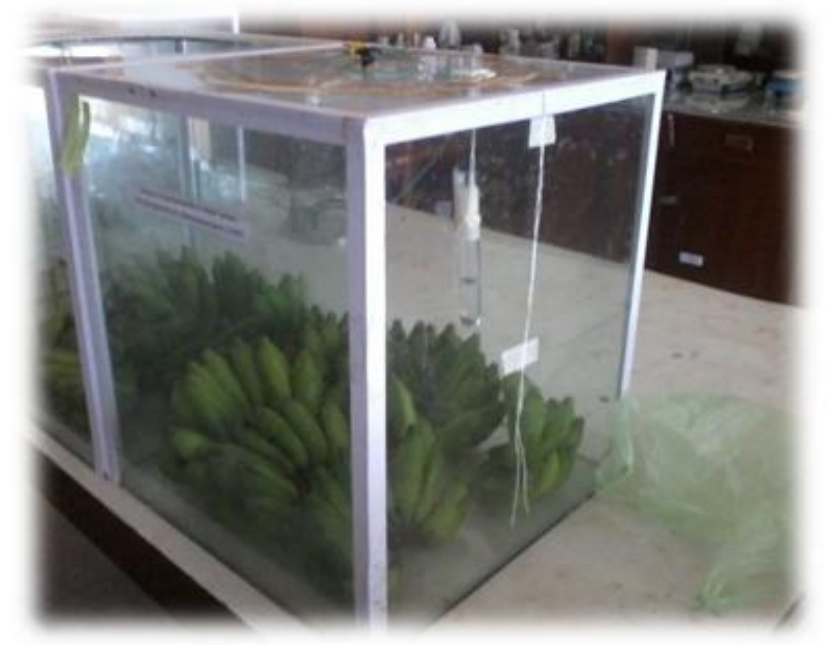

Figure 1. Glass chamber used for 1-MCP treatment

\section{Environmental data collection}

Temperature and relative humidity of atmosphere and in the chamber were recorded before, during and after the treatment, and during the storage period using a digital thermometer (Model: TECPEL 506B) and a digital hygrometer (Model: GMK 930HT), respectively.

\section{Determination of respiration rate and ethylene production}

The respiration rate was measured based on changes in $\mathrm{CO}_{2}$ emission by the fruit, as in Nishshanka et al. (2005). Banana fruit samples from each treatment were placed in air-tight glass containers of a constant volume at ambient condition for one hour. Gas samples were collected using a plastic syringe before treatment, after the treatment and during the storage period. Temperature was measured using a digital thermometer Model TECPEL 506B. Gas samples were collected from containers and analyzed for $\mathrm{CO}_{2}$ production rate and ethylene production using a Gas Chromatograph (Model: SHIMADZU, GC 2014, Colum temparatue: $40{ }^{\circ} \mathrm{C}$, Carrier gas; Helium).

\section{Determination of pulp-to-peel ratio}

Pulp-to-peel ratio of banana fruit samples was determined by dividing the weight of pulp by weight of peel as described by Dadzie and Orchard (1997).

\section{Sugar analysis}

For sugar determination, pulp (10 g) from fruits was homogenized in $80 \%$ ethanol for $1 \mathrm{~min}$ at $5000 \mathrm{rpm}$. The slurry was immediately boiled for $15 \mathrm{~min}$, cooled and filtered. The residue was rinsed with additional ethanol and dried at $70{ }^{\circ} \mathrm{C}$ to obtain the alcohol insoluble solids (AIS) for starch analysis. The filtrate was brought to a 
final volume of $100 \mathrm{~mL}$ with $80 \%$ ethanol. High Performance Liquid Chromatography (HPLC) (Model: Thermo, Doinex Ultimate 300) was used to separate and quantify the amounts of glucose, fructose and sucrose in the banana samples. Sucrose, glucose and fructose peaks of the samples were identified according to HPLC retention times in comparison with authentic standards (Column oven temperature: $43{ }^{\circ} \mathrm{C}$, Detective flow rate: $1 \mathrm{~mL} / \mathrm{min}$, Mobile phase: Acetonitrile to water 75:25).

\section{Determination of ascorbic acid content}

A sample of $20 \mathrm{~g}$ of the fruit was homogenized with $30 \mathrm{~mL}$ extraction solvent (3\% metaphosporic acid) and centrifuged at $15,000 \mathrm{~g}$ for $25 \mathrm{~min}$ at $4{ }^{\circ} \mathrm{C}$. Thereafter, the slurry was filtered through Whatman No. 4 filter paper and then through membrane Miliphore $(0.45 \mu \mathrm{m})$ prior to injection into High Performance Liquid Chromatography (HPLC) (Model: Thermo, Doinex Ultimate 300) system. Separation of ascorbic acid was performed by HPLC with a Gilson UV/Vis 151 Series HPLC system (operated at 230 $\mathrm{nm}$ ) and injection valve with a $100 \mathrm{RP}-18$ column. The flow rate was maintained at 0.5 $\mathrm{mL} / \mathrm{min}$. Data were integrated by Trilution LC software and results were obtained by comparison with standards (Albuquerque $e t$ al., 2005).

\section{Determination of titratable acidity (TA) and juice pH}

Fruit juice, extracted from banana, was used to measure TA by titrating with $0.1 \mathrm{~mol} / \mathrm{L}$ $\mathrm{NaOH}$, using $1 \%$ phenolphthalein as an indicator. The results were expressed as percentage malic acid as described by Diny et al. (2007). The $\mathrm{pH}$ of the fruits was measured using a glass electrode $\mathrm{pH}$ meter (Model: Thermo Orion 420). The $\mathrm{pH}$ was calculated with buffer at $\mathrm{pH} 4.0$ and 7.0 before being used.

\section{Data analysis}

The experimental design adopted was the Completely Randomized Design (CRD). Parametric data gathered were analyzed using Analysis of Variance (ANOVA) by Statistical Analysis System. Differences among treatment means were obtained by Duncan's multiple range test at 5\% significance level $(p \leq 0.05)$.

\section{RESULTS AND DISCUSSION}

\section{Effect of 1-MCP on ethylene production}

As shown in the Figure 2, 1-MCP significantly altered the ethylene climacteric peak in 'Ambul' banana cultivar stored under ambient conditions. Ethylene production rate in control fruits sharply increased during the first five days of storage reaching the peak at day-5. However, 1-MCP-treated fruits significantly delayed the peak of subsequent ethylene production; $0.5 \mathrm{ppm}$ MCP for $12 \mathrm{~h}$ (T1) and $0.5 \mathrm{ppm}$ MCP for $18 \mathrm{~h}$ (T2) until 13 days, and 1 ppm 1-MCP for 12 (T3) and $18 \mathrm{~h}$ (T4) until 17 and 19 days, respectively. This clearly shows that, application of 1-MCP on banana fruits with different concentrations and exposure time periods at ambient conditions exhibits significant differences in delaying ethylene production peaks. The degrees of response on banana fruit to 1-MCP treatment depended largely on the interaction between concentration and exposure time. Application of 1-MCP suppresses ethylene production in banana fruits (Huber, 2008; Hagan et al., 2017) by blocking the normal feedback regulation of ethylene production thereby delaying the ripening. As reported previously, treatment duration of 1-MCP ranged from 12 to $24 \mathrm{~h}$, which was sufficient to achieve the maximum response of fruits (Jeong et al., 2002). Although 1-MCP delayed the ripening in banana, treated fruits again responded to ethylene due to synthesis of new ethylene sites on fruits. Blankenship (2001) mentioned that ethylene and receptor site formation is a continuous process, and 1-MCP do not bind to the receptor site permanently. Then, new receptor sites can be generated resulting regaining sensitivity for ethylene, once the entire available 1-MCP molecules have been used up to block available receptor sites. These results indicated that application of 1- 
MCP at the rate of $1 \mathrm{ppm}$ for $18 \mathrm{~h}$ could extend the shelf life of 'Ambul' banana up to 19 days at ambient conditions.

\section{Effect of 1-MCP on respiration rate}

Respiration rate of banana fruits treated with different dosages of 1-MCP and stored at ambient conditions is shown in Figure 3. The $\mathrm{CO}_{2}$ production rate exhibited the characteristic climacteric respiratory pattern in 'Ambul' banana under ambient conditions. The respiration rate in untreated fruits gradually increased to the maximum rate of $51 \mu \mathrm{L} / \mathrm{kg} /$ hour on day- 5 of storage and then decreased. However, banana fruits treated with 1-MCP showed a significantly lower respiration rate compared to the control during this initial period. In fact, delayed onsets of the respiratory climacterics were clearly observed in banana fruits treated with different concentrations of 1-MCP. Golding et al. (1998) and Mainardi et al. (2007) also reported that ripening of banana was clearly affected by the 1-MCP treatments with a suppression of respiration. The preclimacteric phases of banana fruits treated with different dosages of 1-MCP remained as 9 days for fruits treated with $0.5 \mathrm{ppm}$ of 1 MCP for 12 and $18 \mathrm{~h}$, and 15 days for fruits treated with $1 \mathrm{ppm}$ for $12 \mathrm{~h}$. The most delayed respiration peak was observed at 19 days after the treatment in the fruits treated with $1 \mathrm{ppm}$ for $18 \mathrm{~h}$. Silva et al. (2010) also reported a dose-dependent suppression of respiration peaks in 'Prata' bananas for different number of days.

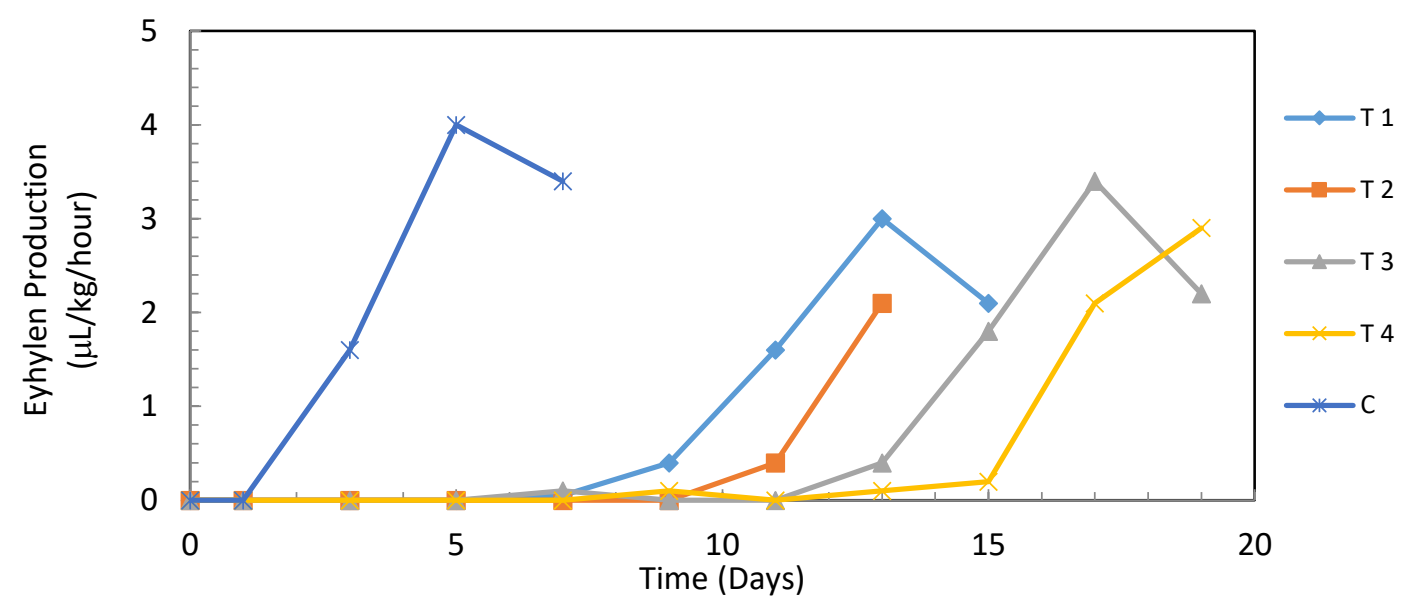

Figure 2. Ethylene production in 1-MCP treated banana fruits during storage period.

(T1: 1-MCP $0.5 \mathrm{ppm}$ for $12 \mathrm{~h}$; T2: 1-MCP $0.5 \mathrm{ppm}$ for $18 \mathrm{~h}$; T3: 1-MCP $1 \mathrm{ppm}$ for $12 \mathrm{~h}$; T4: 1 -MCP $1 \mathrm{ppm}$ for $18 \mathrm{~h}$; C: Control, without $1-\mathrm{MCP}$ )

\section{Effect of 1-MCP on juice pH}

The juice $\mathrm{pH}$ in the banana fruits treated with different dosages of 1-MCP is presented in Table 1. During the storage period, $\mathrm{pH}$ of banana fruits decreased in all treatments and in control. Within first five days, $\mathrm{pH}$ value gradually decreased in the control and showed significantly lower $(\mathrm{p} \leq 0.05)$ values compared to that of 1-MCP treated fruits.
The $\mathrm{pH}$ of 1-MCP treated fruits remained unchanged at the initial days and decreased with the initiation of ripening as I-MCP treatment delayed the ripening of banana. This decrease in $\mathrm{pH}$ in the fruit might have been mainly due to the production of malic acid during the ripening process. Similar results have been reported by Newilah et al. (2009) and Sen et al. (2012). 


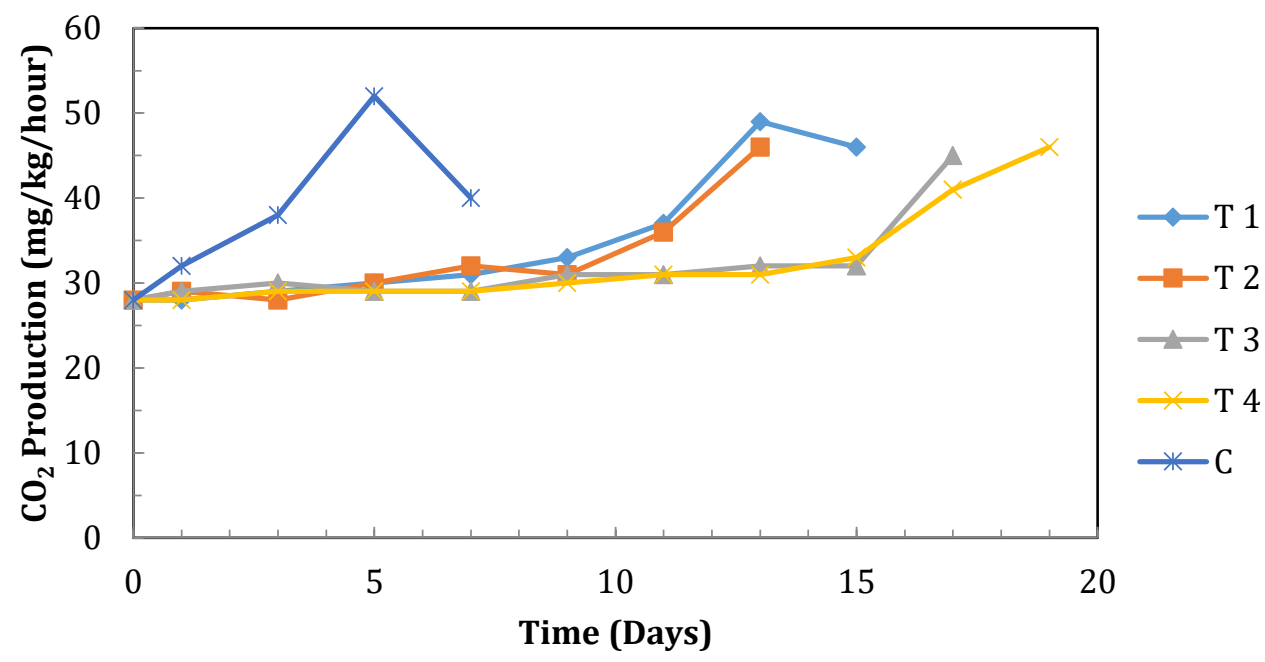

Figure 3. Effect of 1-MCP on the respiration rate of banana during the storage.

(T1: 1-MCP $0.5 \mathrm{ppm}$ for $12 \mathrm{~h}$; T2: 1-MCP $0.5 \mathrm{ppm}$ for $18 \mathrm{~h}$; T3: 1-MCP $1 \mathrm{ppm}$ for $12 \mathrm{~h}$; T4: 1 -MCP $1 \mathrm{ppm}$ for $18 \mathrm{~h}$; C: Control, without $1-\mathrm{MCP}$ )

Table 1. Juice pH of 1-MCP treated banana fruits during ambient storage period.

\begin{tabular}{lrlllllllllllr}
\hline & \multicolumn{10}{c}{ Juice $\mathrm{pH}$ on days of storage } \\
\cline { 2 - 13 } $\begin{array}{c}\text { 1-MCP } \\
\text { dose }\end{array}$ & 0 & 1 & 3 & 5 & 7 & 9 & 11 & 13 & 15 & 17 & 19 \\
\hline T1 & $5.24^{\mathrm{a}}$ & $5.26^{\mathrm{a}}$ & $5.00^{\mathrm{ab}}$ & $5.08^{\mathrm{b}}$ & $4.88^{\mathrm{b}}$ & $4.91^{\mathrm{b}}$ & $4.87^{\mathrm{c}}$ & $4.35^{\mathrm{b}}$ & - & - & - \\
T2 & $5.24^{\mathrm{a}}$ & $5.24^{\mathrm{a}}$ & $5.21^{\mathrm{a}}$ & $5.02^{\mathrm{b}}$ & $5.05^{\mathrm{ab}}$ & $4.86^{\mathrm{b}}$ & $4.40^{\mathrm{d}}$ & $4.41^{\mathrm{b}}$ & - & - & - \\
T3 & $5.24^{\mathrm{a}}$ & $5.24^{\mathrm{a}}$ & $5.23^{\mathrm{a}}$ & $5.24^{\mathrm{a}}$ & $5.12^{\mathrm{ab}}$ & $5.05^{\mathrm{ab}}$ & $4.95^{\mathrm{ab}}$ & $4.55^{\mathrm{a}}$ & $4.60^{\mathrm{a}}$ & $4.54^{\mathrm{a}}$ & - \\
$\mathrm{T} 4$ & $5.24^{\mathrm{a}}$ & $5.25^{\mathrm{a}}$ & $5.31^{\mathrm{a}}$ & $5.20^{\mathrm{a}}$ & $5.24^{\mathrm{a}}$ & $5.19^{\mathrm{a}}$ & $5.11^{\mathrm{a}}$ & $5.01^{\mathrm{a}}$ & $4.79^{\mathrm{a}}$ & $4.62^{\mathrm{a}}$ & 4.50 \\
$\mathrm{C}$ & $5.24^{\mathrm{a}}$ & $5.32^{\mathrm{a}}$ & $4.92^{\mathrm{b}}$ & $4.25^{\mathrm{c}}$ & - & - & - & - & - & - & - \\
\hline
\end{tabular}

(T1: 1-MCP 0.5 ppm for $12 \mathrm{~h}$; T2: 1-MCP $0.5 \mathrm{ppm}$ for $18 \mathrm{~h}$; T3: 1-MCP $1 \mathrm{ppm}$ for $12 \mathrm{~h}$; T4: 1-MCP $1 \mathrm{ppm}$ for $18 \mathrm{~h}$; C: Control, without $1-\mathrm{MCP}$ )

Means with the same letters within columns are not significantly different ( $p>0.05)$

\section{Effect of 1-MCP on pulp-to-peel ratio}

The pulp-to-peel ratio of all the treatments and the control increased from 2.42 to a range of $6.56-7.58$ as the ripening advanced. During initial stages, pulp-to-peel ratio of untreated fruits was significantly higher $(\mathrm{p} \leq 0.05)$ than in all the treatments. The pulp-to-peel ratio of banana fruits increases as the ripening advances due to conversion of starch into sugars and the loss of moisture from the peel through transpiration (Kumar et al., 2018). Banana fruits treated with 1-MCP showed a slower rate of changing of the ratio, resulting in the slowest change in the fruits treated with 1 ppm MCP for $18 \mathrm{~h}$. This might be due to the delay in the moisture loss from the peel and also due to delay in the conversion of starch into sugars since 1-MCP delays ripening by blocking ethylene receptor sites thus preventing ethylene action. Borges et al. (2019) stated that the increase of the pulpto-peel ratio can be attributed to the migration of water from peel to the pulp because of the osmotic gradient, and due to the increase of the sugar contents in the pulp, in relation to the peel. 
Table 2. Effect of 1-MCP on pulp-to-peel ratio of 'Ambul' banana stored at ambient conditions.

\begin{tabular}{lllllllllllll}
\hline & \multicolumn{10}{c}{ Pulp to peel ratio } \\
\cline { 2 - 13 } & Initial & Day 1 & Day & Day & Day 7 & Day & Day11 & Day13 & Day15 & Day17 & Day19 \\
& & 3 & 5 & & 9 & & & & & \\
\hline T1 & $2.42^{\mathrm{a}}$ & $2.69^{\mathrm{ab}}$ & $2.68^{\mathrm{b}}$ & $2.92^{\mathrm{b}}$ & $3.80^{\mathrm{a}}$ & $5.03^{\mathrm{a}}$ & $5.64^{\mathrm{a}}$ & $7.58^{\mathrm{a}}$ & - & - & - \\
$\mathrm{T} 2$ & $2.42^{\mathrm{a}}$ & $2.41^{\mathrm{b}}$ & $2.2^{\mathrm{b}}$ & $3.01^{\mathrm{b}}$ & $3.10^{\mathrm{ab}}$ & $4.95^{\mathrm{a}}$ & $5.24^{\mathrm{a}}$ & $6.99^{\mathrm{a}}$ & - & - & - \\
$\mathrm{T} 3$ & $2.42^{\mathrm{a}}$ & $2.46^{\mathrm{b}}$ & $2.62^{\mathrm{b}}$ & $2.64^{\mathrm{c}}$ & $2.63^{\mathrm{b}}$ & $2.80^{\mathrm{a}}$ & $2.85^{\mathrm{b}}$ & $4.54^{\mathrm{c}}$ & $6.45^{\mathrm{a}}$ & $6.56^{\mathrm{a}}$ & - \\
$\mathrm{T} 4$ & $2.42^{\mathrm{a}}$ & $2.42^{\mathrm{b}}$ & $2.61^{\mathrm{b}}$ & $2.60^{\mathrm{c}}$ & $2.74^{\mathrm{b}}$ & $2.78^{\mathrm{a}}$ & $2.80^{\mathrm{b}}$ & $3.13^{\mathrm{d}}$ & $3.12^{\mathrm{b}}$ & $5.97^{\mathrm{a}}$ & 7.12 \\
$\mathrm{C}$ & $2.42^{\mathrm{a}}$ & $2.80^{\mathrm{a}}$ & $4.47^{\mathrm{a}}$ & $6.93^{\mathrm{a}}$ & - & - & - & - & - & - & - \\
\hline
\end{tabular}

(T1: 1-MCP $0.5 \mathrm{ppm}$ for $12 \mathrm{~h}$; T2: 1-MCP $0.5 \mathrm{ppm}$ for $18 \mathrm{~h}$; T3: 1-MCP $1 \mathrm{ppm}$ for $12 \mathrm{~h}$; T4: 1-MCP $1 \mathrm{ppm}$ for $18 \mathrm{~h}$; C: Control, without $1-\mathrm{MCP}$ )

Means with the same letters within columns are not significantly different ( $p>0.05)$

\section{Effect of 1-MCP on Ascorbic Acid content}

As shown in the Figure 4, ascorbic acid content of 'Ambul' banana fruits in all the treatments increased gradually during the storage period at ambient conditions. Fruits in the control showed a rapid increase in ascorbic acid content within 5 days. The increase in levels of ascorbic acid with ripening has been attributed to the increase in lipid peroxidation as fruit ripening which is an oxidative process that requires turnover of active oxygen species (Fernando et al., 2014). This correlates well with the decrease in fruit $\mathrm{pH}$ with the ripening. However, all combinations of treatments indicated a significantly $(\mathrm{p} \leq 0.05)$ lower ascorbic acid content than control until 10 days of storage. In addition, rates of changing the ascorbic acid content among treatments were different and $\mathrm{T} 4$ showed the least increasing rate from $11 \mathrm{mg} / 100 \mathrm{~g}$ to 25 $\mathrm{mg} / 100 \mathrm{~g}$ during 19 days.

\section{Effect of 1-MCP on sugar composition of fruit}

Figure 5 shows the changes in sucrose, fructose and glucose concentrations in 1MCP treated 'Ambul' banana fruits during the storage period. All the treatments and control exhibited a progressive increase in sucrose, fructose and glucose contents during fruit storage period (Fig: $5 \mathrm{a}, 5 \mathrm{~b}$ and $5 c$ respectively). As described by Tapre and Jain (2012), the increase in sugar contents in banana is due to the hydrolysis of starch into simple sugars. The sugar contents in the control under ambient storage showed faster rates of starch hydrolysis and after 7 days, a level of $15.7 \mathrm{mg} / \mathrm{g}$ of sucrose, 6.4 $\mathrm{mg} / \mathrm{g}$ of fructose and $3.4 \mathrm{mg} / \mathrm{g}$ glucose was detected in fruits on fresh weight basis. However, after 7 days, the sugar contents in banana fruits treated with 1-MCP were significantly lower $(p \leq 0.05)$ compared to that of control. The lowest change in sugar contents, except glucose, during storage period was recorded in T4 that took the longest time to ripe. According to the Golding et al. (1998) the inhibition of respiration in fruits by 1 -MCP effects on carbohydrate metabolism during the ripening.

\section{Effect of 1-MCP on Titratable Acidity (TA)}

The change in titratable acidity (TA) of banana as a function of different 1- MCP concentrations and storage time is shown in Figure 8. Results showed that there was an increase in TA for both 1-MCP-treated and control fruits during storage period. As reported by Hagan et al. (2017), TA of banana fruits considerably increased during the ripening process. A rapid rise in TA of control sample was observed at the initial stage of storage period and this was significantly higher $(\mathrm{p} \leq 0.05)$ than in treatments. Banana fruits treated with different dosages of 1-MCP suppressed the rate of increase in TA until 7 - 14 days of storage and rapid increase was observed 
thereafter with the onset of ripening process. Similar results were reported earlier by Rahman et al. (2014). Fan et al.
(1999) showed that 1-MCP treatments can maintain acidity levels in agriculture commodities.

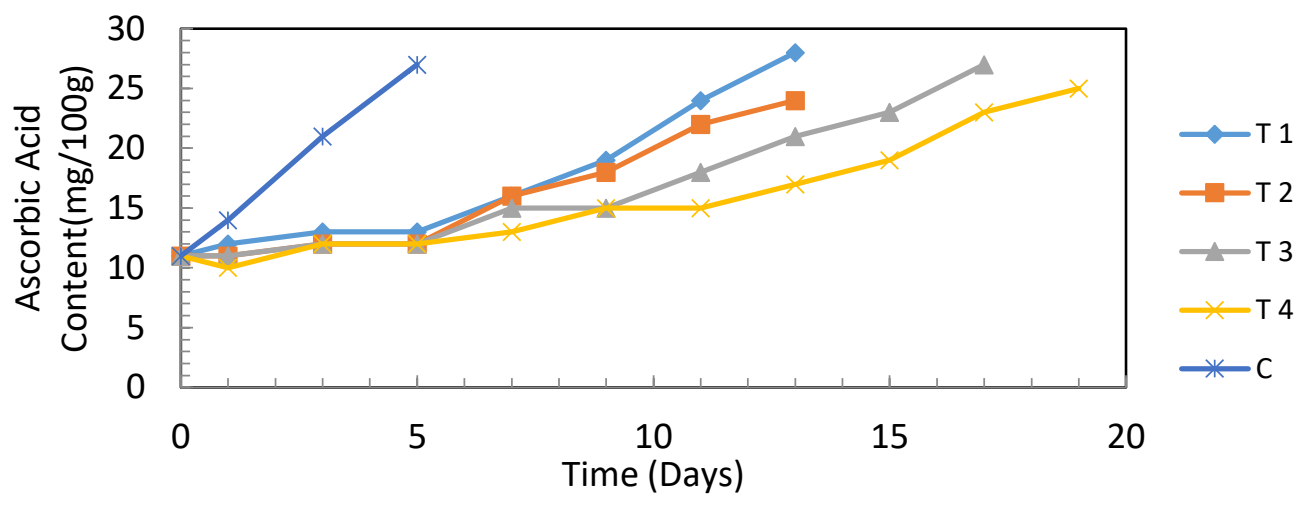

Figure 4. Change in Ascorbic Acid content of 1-MCP treated banana.

(T1: 1-MCP $0.5 \mathrm{ppm}$ for $12 \mathrm{~h}$; T2: 1-MCP $0.5 \mathrm{ppm}$ for $18 \mathrm{~h}$; T3: 1-MCP $1 \mathrm{ppm}$ for $12 \mathrm{~h}$; T4: 1-MCP $1 \mathrm{ppm}$ for $18 \mathrm{~h}$; C: Control, without 1-MCP)
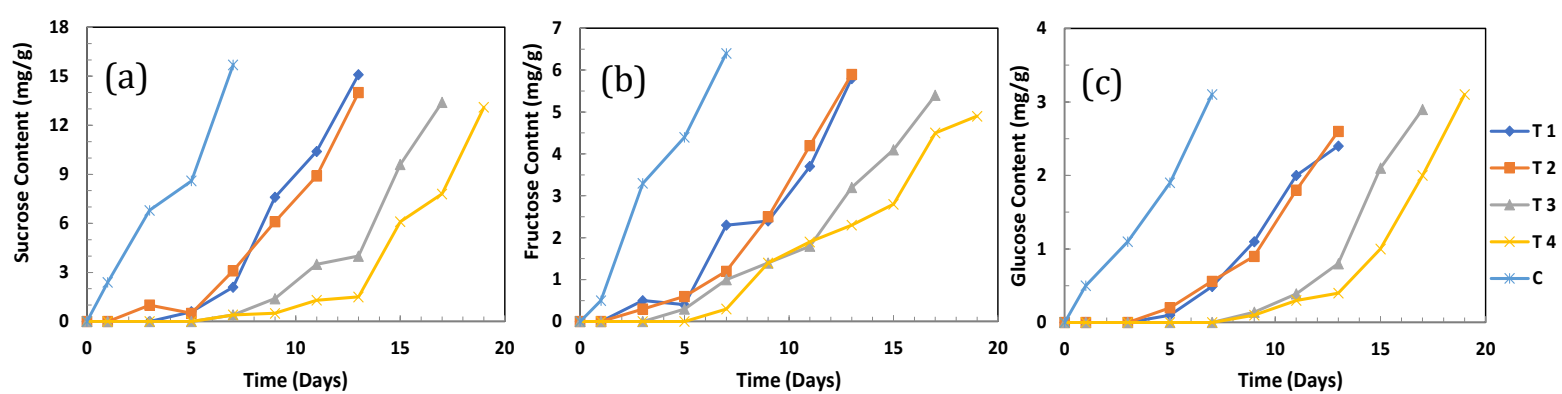

Figure 5. Changes in (a) sucrose, (b) fructose and (c) glucose contents as affected by 1-MCP treatment in banana fruits during ambient storage $\left(29 \pm 5^{\circ} \mathrm{C}\right.$ and $\left.69 \pm 7 \% \mathrm{of} R \mathrm{RH}\right)$.

(T1: 1-MCP $0.5 \mathrm{ppm}$ for $12 \mathrm{~h}$; T2: 1-MCP $0.5 \mathrm{ppm}$ for $18 \mathrm{~h}$; T3: 1 -MCP $1 \mathrm{ppm}$ for $12 \mathrm{~h}$; T4: 1 -MCP $1 \mathrm{ppm}$ for $18 \mathrm{~h}$; C: Control, without $1-\mathrm{MCP}$ )

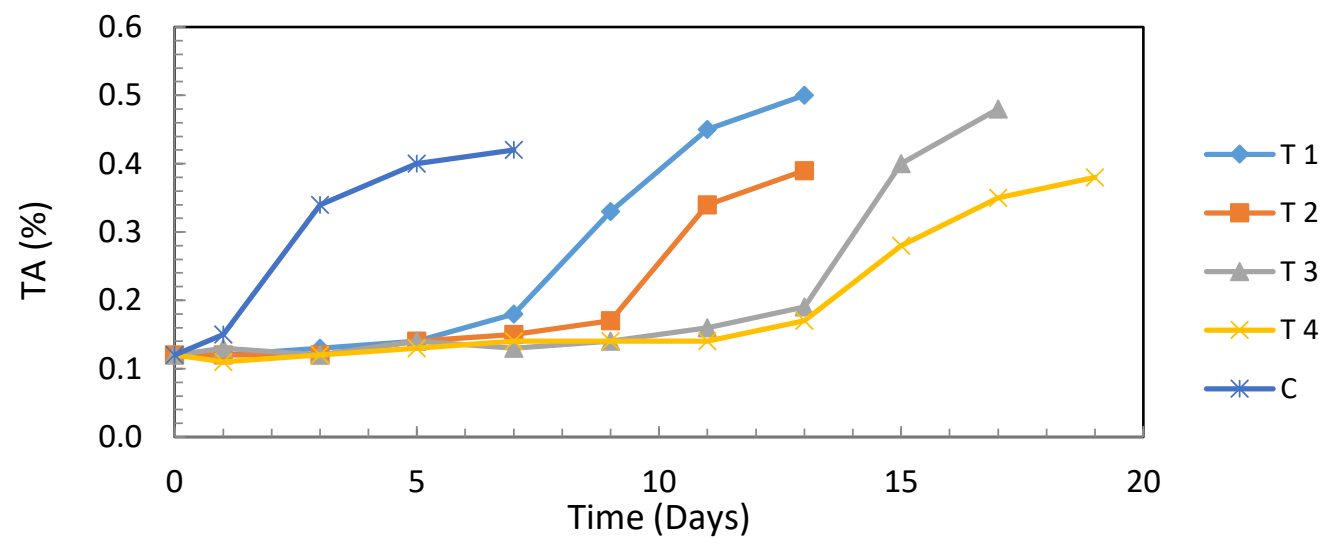

Figure 6. Effect of 1-MCP application on TA of banana fruits at ambient conditions $\left(29 \pm 5^{\circ} \mathrm{C}\right.$ and $69 \pm 7 \%$ of $\mathrm{RH}$ ).

(T1: 1-MCP 0.5 ppm for $12 \mathrm{~h}$; T2: 1-MCP $0.5 \mathrm{ppm}$ for $18 \mathrm{~h}$; T3: 1-MCP $1 \mathrm{ppm}$ for $12 \mathrm{~h}$; T4: 1-MCP $1 \mathrm{ppm}$ for $18 \mathrm{~h}$; C: Control, without 1-MCP) 


\section{CONCLUSION}

The research confirms that application of 1methylcyclopropene (1-MCP) clearly delayed the ripening of 'Ambul' banana stored at ambient conditions. Evidently, 1MCP suppressed most of biochemical changes associated with banana ripening.

\section{REFERENCES}

Albuquerque, B., Lidon, F.C. and Leitão, A.E. (2005). Ascorbic acid quantification in melon samples - The importance of the extraction medium for HPLC analysis. General and Applied Plant Physiology. 31(3), 275-251.

Blankenship, S.M. and Dole J.M. (2003). 1Methylcyclopropene: A review. Postharvest Biology and Technology. 28, 1-25.

Borges, C.V., Amorim, M.L., Gomez, H.A.G., Leonel, M., Santos, T.P.R., Ledo, C.A.S., Belin, M.A.F., Almeida, S.L., Minatel, I.O. and Lima, G.P.P. (2019). Post-harvest physicochemical profile and bioactive compounds of 19 bananas and plantains genotypes. Bragantia. 78(2), http://dx.doi.org/10.1590/16784499.20180252

Dadzie, B.K. and Orchard, J.E. (1997). Routing postharvest screening of banana/plantain hybrids: criteria and methods. INIBAP technical guidelines No. 2. INIBAP, Montpelier.

Ding, P., Ahmad, S.H., Abd Razak, A.R., Mohamed, M.T.M. and Saari, N. (2007). Changes in selected quality characteristics of minimally processed carambola (Averrhoa carambola L.) when treated with ascorbic acid. Journal of the Science of Food and Agriculture. 87, 702 - 209.

Fan, X., Blankenship, S.M. and Mattheis, J.P. (1999). 1-Methylcyclopropene inhibits apple ripening. Journal of the
Regulation of ripening related biochemical parameters reflect the inhibition of ethylene action at post-treatment duration. Treating 'Ambul' banana with 1-MCP at the dose of 1 ppm for 18 hours extended the shelf life for 19 days under ambient conditions (temperature: $29 \pm 5^{\circ} \quad \mathrm{C}$ and relative humidity: $69 \pm 7 \%$ ).

American Society for Horticultural Science. 124, 690-695.

Fernando, H.R.P., Srilaong, V., Pongprasert, N., Boonyaritthongchai, P. and Jitareerat, P. (2014). Changes in antioxidant properties and chemical composition during ripening banana variety 'Hom Thong' (AAA group) and 'Khai' (AA group). International Food Research Journal. 21(2), 749-754.

Golding, J.B., Sheater, D., Wyllie, S.G. and McGlasson, W.B. (1998). Application of 1-MCP and propylene to identify ethylene dependent ripening process in mature banana fruit. Postharvest Biology and Technology. 14(1), 87-98.

Hagan, L.L., Johnson, P.N.T., Sargent, S.A., Huber, D.J. and Berry, A. (2017). International Food Research Journal. 24(2), 630-636.

Hirimburegama, W.K., Dias, W.K.G. and Hirimburegama, K. (2004). Banana improvement through gamma irradiation and testing for banana bract mosaic virus in Sri Lanka. FAO corporate document repository. Available at http://www.fao.org/docrep/007/ae2 16e/ ae216e09.htm\#TopOfPage.

Huber, D.J. (2008). Suppression of ethylene responses through application of 1methylcyclopropene: a powerful tool for elucidating ripening and senescence mechanisms in climacteric and non-climacteric fruits and vegetables. HortScience. 43(1), 106111. 
Jeong, J., Huber, D.J. and Sargent, S.A. (2002). Influence of 1-methylcyclopropene (1MCP) on ripening and cell-wall matrix polysaccharides of avocado (Persea americana) fruit. Postharvest Biology and Technology. 25, 241-364.

Jiang, Y., Joyce, D.C. and Macnish A.J. (1999). Responses of banana fruit to treatment with 1-methylcyclopropene. Plant Growth Regulation. 28(2), 77-82.

Jinasena, D., Pathirathna, P., Wickramarachchi S. and Marasinghe E. (2011). Effect of chitosan (unirradiated and irradiated) treatment on anthracnose disease and Its potential to increase the shelf life of Embul banana, International Journal of Environmental Science and Development, 2(4), 248-252.

Kumar, T.K., Bhagavan, B.V.K., Mamatha, K., Snehalatha, A. and Subbaramamma, P. (2018). Response of 1-MCP on Physiological and Physical Characteristics in Banana (Musa paradisiaca L.) cv. Tella Chakkerakeli during Storage, International Journal of Current Microbiology and Applied Sciences. 7(12), 3135-3144.

Mainardi, J.A., Purgatto, E., Vieira, A., Bastos, Cordenunsi, B.R., Nascimento, R.O.D. and Lajolo, F.M. (2007). Effects of ehylene and 1-Methylcyclopropene (1MCP) on gene expression and activity profile of r-1,4-Glucan-phosphorylase during banana ripening, International Journal of Food Science and Technology. 42, 303-311.

Newilah, N.G., Brat, P., Tomekpe, K., Alter, P., Fokou, E. and Etoa, F.X. (2010). Effect of ripening on total polyphenol contents of Musa Hybrids and cultivars grown in Cameroon. Acta Horticulture. 879,45 .

Nissanka, L.N.M.S., Dharmasena, D.A.N., Wickramasinghe, R.W.M.R.K., Jayathunge, K.G.L.R. and Sumanarathne, J.P. (2005). Fruit characterization and establishment of maturity indices for spine gourd (Memordia dioica), First national symposium on Innovative Approaches in Post-Harvest Engineering and Technology held on 20 $0^{\text {th }}$ Dec., 2005, Peradeniya, Sri Lanka.

Rahman, M.A., Hossain, M.A., Begum, M.M., Banu S.P. and Arfin, M.S. (2014). Evaluating the Effects of 1Methylcyclopropene Concentration and Immersion Duration on Ripening and Quality of Banana Fruit. Journal of Postharvest Technology. 2(1), 54-67.

Sen C., Mishra, H.N. and Srivastav, P.P. (2012). Modified atmosphere packaging and active packaging of banana (Musa spp.): A review on control of ripening and extension of shelf life. Journal of Stored Products and Postharvest Research. 3(9), 122 - 132.

Seymour, G.B., Taylor, J.E. and Tucker, G.A. (1993). Biochemistry of fruit ripening. Chapman \& Hall, London.

Silva, S.M., Neto, C.O., Alves, R.E. and Silva, E.O. (2010). Maturation physiology under modified atmosphere of 'Prata' banana treated postharvest with 1Methylecyclopropene. Proc.III Intternational Symposium on Tropical and Subtropical fruits, (pp. 371-377). Brazil.

Tapre, A.R. and Jain, R.K. (2012). Study of advanced maturity stages of banana. International Journal of Advanced Engineering Research and Studies. 1(3), 272-274.

Wasala, W.M.C.B., Dissanayake, C.A.K., Dharmasena, D.A.N., Gunawardane, C.R. and Dissanayake, T.M.R. (2014). Postharvest Losses, Current Issues and Demand for Postharvest Technologies for Loss Management in the Main Banana Supply Chains in Sri Lanka. Journal of Postharvest Technology. 2(1), 80-87. 
Zhang, M.J., Jiang, Y.M., Jiang, W.B. and Liu, X.J. (2006). Regulati of ethylene synthesis of harvested banana fruit by 1Methylcyclopropene. Food Technology and Biotechnology. 44(1), 111-115.
https://knoema.com/atlas/SriLanka/topics/Agriculture/CropsProduction-Quantitytonnes/Bananas-production. [Accessed on 15.07.2019] 